\title{
The Impact of Returned Product Disposition Strategies on Organizational Performance Applied to the Egyptian Household Appliance Industry
}

\author{
Ahmed Attia ${ }^{1}$ \\ ${ }^{1}$ Faculty of Commerce, Damanhour University, Egypt \\ Correspondence: Ahmed Attia, Faculty of Commerce, Damanhour University, Egypt. E-mail: \\ ahmed.attia@damanhour.edu.eg
}

Received: June 8, 2015

Accepted: July 7, 2015

Online Published: August 22, 2015

doi:10.5539/ijbm.v10n9p143

URL: http://dx.doi.org/10.5539/ijbm.v10n9p143

\begin{abstract}
The purpose of this paper is to examine the effect of returned product disposition strategies on organizational performance by collecting and analysing data from the household appliance industry in Egypt. In addition, this paper also tests the effect of resource allocation as a moderator variable for the relations between disposition strategies and organizational performance. The proposed research model describes the impact of returned product disposition strategies on organizational performance and the effect of resource allocation as a moderator variable for the relations between disposition strategies and organizational performance. The proposed research model and hypotheses were tested using correlation analyses, regression analyses and structural equation modelling based on data collected from 108 companies in the Egyptian household appliance industry.

According to the results of the study, disposition strategies are positively associated with organizational performance. Moreover, resource allocation moderates the relation between disposition strategies and organizational performance. The data used in this study were collected from 108 companies in the Egyptian household appliance industry. However, the generalization of the study results may be limited by the size of the sample. This study provides a useful working model in the household appliance industry. The results suggest that using disposal and repair strategies will contribute to improving organizational performance, and appropriate resource allocation will moderate the relation between disposition strategies and organizational performance.
\end{abstract}

Keywords: returned products, disposition strategies, organizational performance, Egypt

\section{Introduction}

The aim of this research is to investigate different activities related to reverse logistics and its role in creating competitive advantages and improving the company's performance. One of the main activities related to reverse logistics is the disposition of the returned product without polluting the environment as well as reducing the cost of disposition. The current research investigated the effect of different disposition strategies on the company's performance and how to use such strategies to gain competitive advantages and create sustainability. Data from 108 companies in the Egyptian household appliance industry were collected and tested using Correlation Analyses, regression analyses and structural equation modelling.

Reverse logistics is the reverse flow of the product from the point of consumption to the point of producing the product. The product may be returned because it does not fit the customer need, or a part of a product, such as cans, can be returned to be recycled. We could differentiate between the many reasons for returning a product such as the following: faulty order processing, retail overstock, end of product life cycle, product replacement, manufacture recall programs, installation or usage problems, warranty claims, etc. (Schatteman, 2006).

The rate of returned products for online apparel retailers ranges between 35 to $50 \%$; some fashion categories face higher rates, which can reach up to $80 \%$. Furthermore, the average returned products rate for non-fashion categories is approximately 14\% (Martinez, 2009; Roenisch, 2013). According to Schulze et al. (2014), 5\% of the customers who purchased 5 items over a period of 5 years returned $80 \%$ of the products they had bought, and $1 \%$ of the customers returned at least $90 \%$ of the purchased products. In addition, they discovered that the profit of retailers could be higher by $50 \%$ without the cost of returned products. 
Managers are often unaware of the impact returns management can have on their customers, resources or bottom line. In fact, improving reverse logistics can help companies increase revenue up to $5 \%$ of total sales. Companies often view returns as a cost of doing business and ignore the potential revenue opportunity. In the electronics industry, the average return rate on sales is $8 \%$, but the return rate within subcategories can range from $4 \%$ to $15 \%$ (Schulze et al., 2014). This equates to $\$ 14$ billion in annual returns, and many of these products are not defective at all (Petersen \& Kumar, 2010). Years of testing returned consumer electronics have established that the non-defective rate for consumer electronics remains at approximately $65 \%$ of total goods returned, meaning that only $35 \%$ of goods are actually defective (Schulze et al., 2014).

The non-defective product may be in perfect working order or damaged by the customer but still repairable. Lack of experience concerning reverse flows in the supply chain causes limited insight into best practices for managing reverse logistics. Additionally, managers are unaware of opportunities for improving and measuring performance of reverse logistics and how to use it to gain competitive advantages and achieve sustainability (Janse, 2008).

Recently, the topic of managing returns was also taken as part of research priorities, for its nature reverse flow is moving between different supply chain members from downstream to upstream (Guide \& Wassenhove, 2009; Stock et al., 2010; Rogers et al., 2012). The functionally aligned approach to working across the supply chain has become critically important to ensure ongoing and profitable relationships (Blackburn et al., 2004). Therefore, the current research will follow the stream of such studies to try to minimize the gap in the literature. In today's business world, the concern is not only reducing costs to gain more profit, but there is also a shift toward achieving sustainability by achieving the concept of triple bottom line, which demonstrates the need to achieve a balance between social responsibility, environmental preservation and economic prosperity to achieve sustainability (Correa \& Xavier, 2013).

This increase in scholar and practitioner focus reinforces the emergence of returns management as a key strategic capability for any organization within the supply chain. Reverse logistics as a part of any company's activities should be completed with the same concern to achieve the triple bottom line concept (Hazen, 2011; Greve \& Davis, 2012). Dealing with returned products is one of the major activities related to reverse logistics; we could distinguish between several disposition strategies such as recycling and remanufacturing. Each strategy may have a different impact on the environment and company performance. Therefore, each strategy could be used as a tool for achieving competitive advantages and achieving sustainability (Skinner et al., 2008).

The current study focuses on handling returned products as one of the operations of reverse logistics. This would take place through identifying the various strategies adopted while handling returned products as well as stressing on the impact of these strategies on the performance level of the company. Moreover, the study identifies the effect of allocating resources to reverse logistics activities by the company on the hypothetical relation between the disposition strategies of returned products and organizational performance.

The research goals were translated in the following research questions:

1) What are the main currently used disposition strategies?

2) How can reverse logistics performance most effectively be measured?

3) How do companies use disposition strategies to gain competitive advantages?

4) How do companies use different disposition strategies with minimum impact on the environment?

This paper is divided into six sections. The first two sections include the introduction and the literature review, while the third and the fourth sections cover the development of the research hypotheses and the research design methodology. Meanwhile, the fifth section discusses data analysis and results, whereas the discussion and conclusion are presented in the last section.

\section{Literature Review}

\subsection{Disposition Strategies}

In 2001, Trebilock stated that the function of reverse logistics includes five consecutive activities, including: authorizing the collection of returned products from customers, transportation, auditing operations, handling returned products, and establishing a data system to track returned products. However, a group of researchers identified different processes for supply chain and they considered reverse logistics as the second process, which includes different activities such as picking up the product, reverse logistics, auditing and handling returned products, recondition, and remarketing (Prahinski \& Kocabasoglu, 2006).

Meanwhile, in 2008, Skinner et al. described the process of handling returned products as the preparatory 
strategic step towards achieving high performance by the company. On the other hand, Kumar and Putnam (2008) said that companies could gain profits through handling returned products in the right way by remanufacturing and recycling. If companies adopted the strategy of accepting returned products from the customers to achieve customer loyalty, reverse logistics then becomes a vital function that contributes to achieving this strategy, eventually leading to a reduction in the costs of the product (Mollenkopf \& Weathersby, 2003).

In addition, there are a number of elements that should be considered while choosing the best strategy to address returned products. These elements include the complexity of the process of taking apart returned products, effects on the environment, the lifespan and condition of returned products, the quality of the products that are scheduled to be reproduced in comparison to the original product specifications, and the availability of markets for second hand products. (Thierry et al., 1995; Guide et al., 2000; Ijomah et al., 2007; Gehin et al., 2008; Rogers et al., 2010).

For Fernandez et al. (2008), the adopted approach while handling returned products depends on the cost and value of the remanufactured products, the complexity of the product design, and the market value of the product. Meanwhile, in 2003, Norek stated that companies have at least five alternatives to address dispositions:

1) Reselling returned products as good as new products in case customers returned the product because of their dissatisfaction with its performance.

2) Repairing or resealing returned products and selling them as second hand products.

3) Repairing or repack returned products and selling them as new products.

4) Reselling these products with low prices to scrap stores.

5) Selling these products by weight and not by unit to scrap stores.

Moreover, Skinner et al. (2008) pinpointed five disposition strategies for returned products through conducting interviews with a number of logistics managers. These strategies are:

1) Disposal: this strategy is used due to the inability to sell or use dispositions or if returning these products to the company is economically inefficient.

2) Recycling: this strategy is used in case the components of dispositions could be reused in the production of the same product or other products.

3) Reconditioning the returned products.

4) Remanufacturing.

The essential difference between reconditioning and remanufacturing a product lies in the effort needed to enhance and repair returned products. Remanufacturing requires more effort to enhance and repair a product; however, in both cases, returned products are sold right away.

5) Resealing returned products is used in case they did not need any reparation or reconfiguration.

According to Khor and Udin (2012), there are five disposition strategies, which are similar to those suggested by Skinner et al. (2008). These strategies are:

1) Repair: this strategy represents the efforts exerted to exchange or repair the damaged parts of the products to put them back to work in a natural way.

2) Recondition: this strategy involves taking apart the parts of the product that caused the problem to examine, repair or exchange them.

3) Remanufacturing: this strategy includes the total dismantle of the product to examine all of its parts to repair or exchange the damaged ones.

4) Recycling: in this strategy, the proper parts and components are taken out of the product to be reused.

5) Disposal: this strategy is used due to the inability to sell or use dispositions or if returning these products to the company is economically inefficient.

\subsection{Organizational Performance}

According to Slater and Olson (2000), the basic literature hypothesis in the field of strategy application relies on a concept that states that different work strategies require different organizational practices in order to reach optimal performance. Here we notice that a company must efficiently and effectively apply its competitive strategy in a way that contributes to achieving competitive advantages and maintaining those (Morgan et al., 2004). Moreover, one of the important decisions that is linked to the competitive strategy of a company is the 
choice of returned product disposition strategies. The choice of strategy contributes to enhancing the organizational effectiveness in order to achieve excellent performance levels (Slater \& Olson, 2000).

In addition, Khor and Udin (2012) stated that the interests and job descriptions of each organizational department in a company differ. Therefore, the standards of organizational performance will also vary according to different career fields. In the case of handling the function of logistics in general and returned product disposition strategies in particular, relying on financial standards only while measuring performance is not acceptable. However, the environmental dimension must be considered as one of the standards of measuring performance because of its effect on the environment.

\subsection{Allocating Resources}

According to Peteraf (1993), the resources theory is based on a concept that states that resources, which are owned or controlled by a company, can contribute to creating competitive advantages for the company. However, these resources must not be copied or substituted by other competitors. The resources of a company include assets, capabilities, organizational process, organizational characteristics, information, knowledge, etc. The company controls these resources as they enable it to set and execute its strategy in a way that boosts the efficiency and effectiveness of the company (Barney, 1991; Daft, 1983).

There are two approaches in management literature that are concerned with the resources of a company. The first one is linked to research in the field of strategies, as it focuses on the importance of creating a link between the points of strength and weakness of a company while taking into consideration the chances and threats of the external environment (Das \& Teng, 2000). Meanwhile, the second approach stresses the internal aspects of an organization, as studies in this approach focused on the impact of resources owned by the company on its level of performance (Conner, 1991). For their part, Closs and Xu (2000) stated in their study that the performance levels of the function of logistics vary according to the allocation of resources among companies, whereas statistical analysis of a survey conducted by Daugherty et al. (2001) about reverse logistics revealed that the allocation of resources has a direct effect on the capability of reverse logistics to achieve its targets.

Reverse logistics is no longer a tool for minimizing costs only, but it also helps improve sales performance, so reverse logistics will have a positive effect on the company profit margin. In addition, literature in the field of reverse logistics is also concerned with the environment and how companies will address returned products without polluting the environment (Jayaraman, 2007; Xie \& Breen, 2012). Huscroft et al. (2013) tried to identify the convergence and divergence between research and practice in the area of reverse logistics. Their results demonstrated that there is a convergence between research and practice in three issues: customer support, top management support and environmental issues. These three issues represent the future research in the area of reverse logistics (Huscroft et al., 2013).

Research in the area of supply chain in general and in the area of reverse logistics specifically represent an active and new area that still needs to be investigated. In particular, research is needed surrounding how to plan and manage reverse logistics in an efficient and effective way to achieve sustainability and keep the environment green (Govindan et al., 2014; Nuss et al., 2014). The literature on reverse logistics has been reviewed during the last eighteen years by many researchers. They identified different perspectives of studying reverse logistics, such as distribution planning, inventory management, production planning, environmental aspects, packaging, and purchasing. However, different perspectives have not been covered by researchers such as forecasting products return, outsourcing, secondary markets, and dispositions strategies (Agrawal et al., 2015).

In an in-depth reverse logistics literature review of 382 articles by Govindan et al. (2014), they discovered that reverse logistics from adaptation and implementation as well as the dispositions decision perspectives has been covered empirically by several researchers. However, there is a need to explore the different disposition strategies and their effect on performance. In addition, Agrawal et al. (2015) stressed the need for future research covering disposition strategies and filling the literature gap, as they identified a small number of research papers that focused on the effect of disposition strategies.

The proposed research is an attempt to fill the literature gap related to reverse logistics activities and its impact on performance as well as how companies will use disposition strategies as a tool for achieving superior performance.

\section{Development of Research Hypotheses}

Previous reviews of the literature demonstrated that returned product disposition strategies have an impact on the level of performance. This impact controls the capabilities of the company to create competitive advantages. However, according to Daugherty et al. (2001) and Skinner et al. (2008), this effect is linked to allocating 
resources by the company in order to apply disposition strategies. Therefore, the following model was set to reveal the relation between the main variables of the current study.

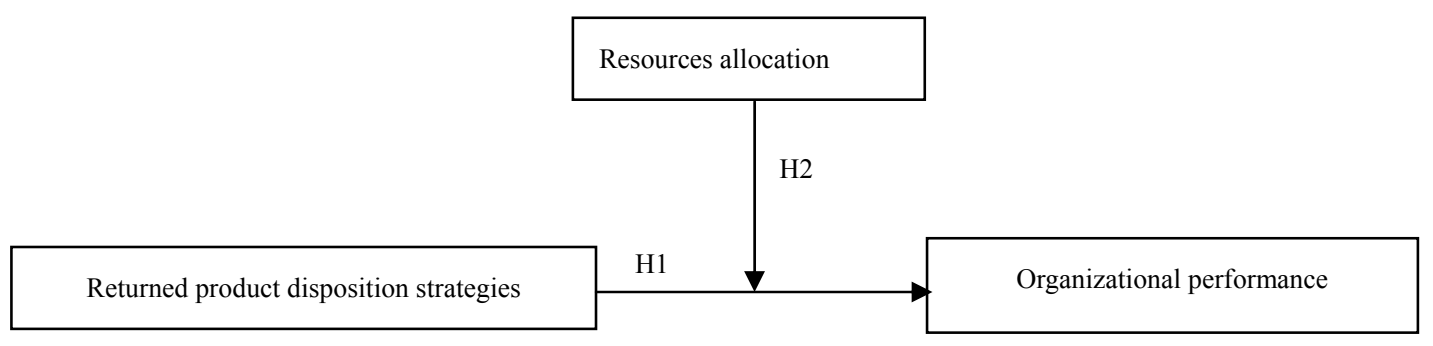

Figure 1. Suggested research model

According to this model, the following hypotheses were set to examine the relation between the variables of the study:

H1. Returned product disposition strategies have a significant impact on organizational performance.

H2. Allocating resources for returned product disposition strategies will moderate the relation between these strategies and organizational performance.

\section{Research Design Methodology}

The qualitative research methodology has been used to identify the disposition strategies used in the Egyptian household industry through in-depth interviews. Additionally, the quantitative research methodology has been used by developing a questionnaire to collect data from the industry.

The applied part of the current study was divided into two parts; the first part includes a survey to identify the availability of returned product disposition strategies in the Egyptian market and to examine the validity and reliability of the adopted measures. Meanwhile, the second part is a descriptive study about the effect of returned product disposition strategies on organizational performance. It also assesses the effect of resource allocation of these strategies on the hypothetical relation between returned product disposition strategies and organizational performance.

The survey was held over two phases: in the first phase, a survey was conducted with 30 companies to identify how far returned product disposition strategies are applied in companies working in the field of Home Appliance in Egypt. No studies have tackled this subject in Egypt because of its novelty, at least as far as the researcher knows. The interviews were held with purchasing and production managers. Several 'yes and no' questions related to different dimensions of returned product disposition strategies were asked, as shown in Table 1 .

Table 1. Interview questions

\begin{tabular}{ll}
\hline Question & Yes No \\
\hline 1-Disposal Strategy Involves: & \\
-Minimizing disposal. & \\
-Appropriate storage of waste. & \\
-Appropriate dumping of waste. & \\
-Appropriate treatment of waste. \\
2-Recycling Strategy Involves: \\
-Collecting used products from customers for recycling. \\
-Collecting used packaging from customers for recycling. \\
-Procedures for recycling. \\
-Procedures for handling hazardous materials for end-of-life products. \\
-Reducing the amount of energy required for extracting virgin material. \\
-Re-melting of materials to make new products. \\
- Energy recycling to extract the heat from burning materials. \\
- Disassembly up to material level. \\
- Reusing materials from used products and components. \\
-Collecting back recyclable product by the suppliers.
\end{tabular}




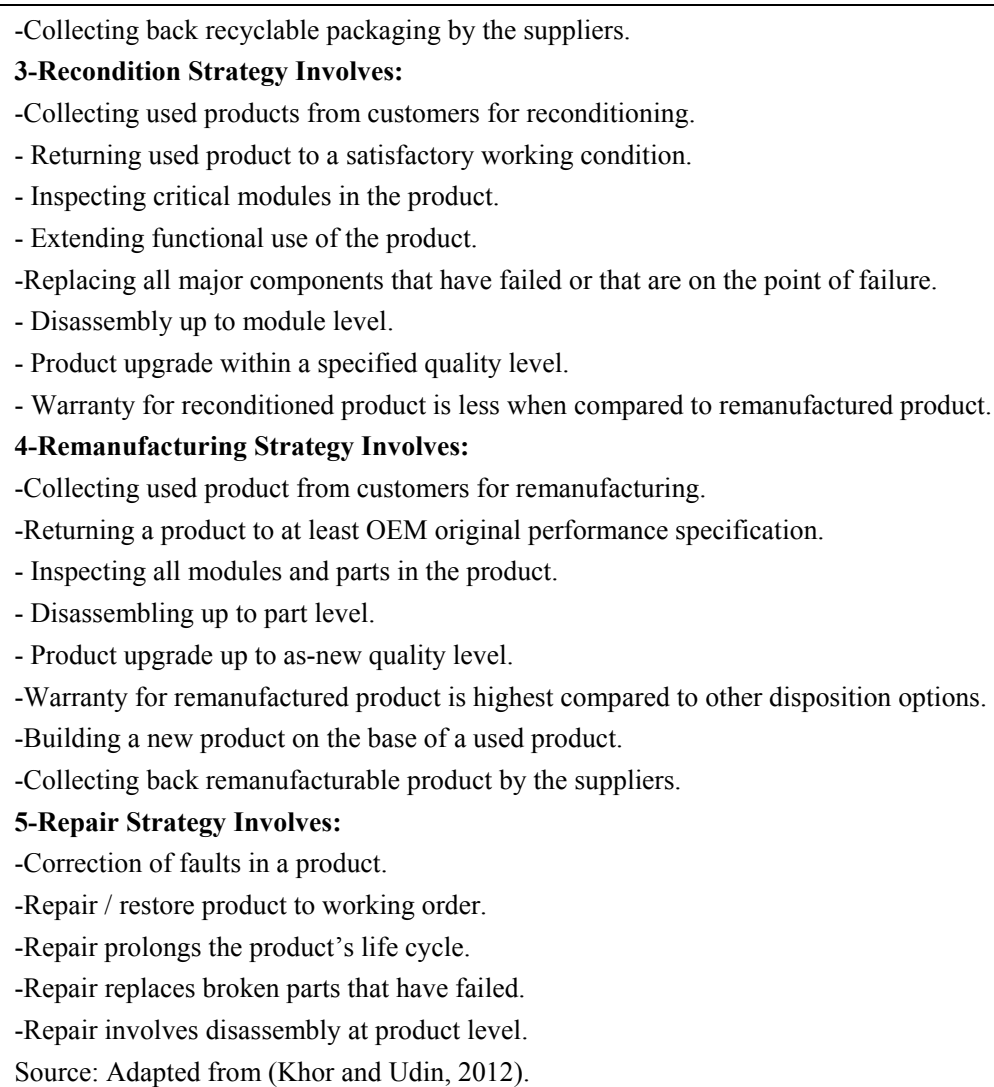

The results of these interviews can be summarized by the following points:

1) The representatives of 28 companies agreed on adopting the dimensions of both disposal and repair strategies.

2) The representatives of only three companies agreed on adopting the dimensions of the recycling strategy.

We can conclude that companies working in the field of Home Appliance Sector in Egypt adopt only the disposal and repair strategies. Therefore, these strategies will be used to refer to returned product disposition strategies in the current study.

In the second phase, a questionnaire was prepared according to the previously mentioned interviews. The questionnaire was presented to the purchasing and production managers of the initial sample of the 30 companies used in the first phase. This phase aimed at examining the validity and reliability of the adopted measures. Moreover, the measures that were developed by Khor and Udin (2012) were adapted to measure both returned product disposition strategies and organizational performance. Meanwhile, measuring the allocation of resources depended on the measure that was developed by Skinner et al. (2008).

\subsection{Descriptive Study}

The current research focuses on the household appliance industry in Egypt, in which 178 working companies are involved, according to the CAMPAS 2013 statistical yearbook (http://www.capmas.gov.eg). The questionnaire was presented to the purchasing and production managers of the 178 companies working in the field of Home Appliance.

The questionnaire was sent by mail and was followed up by a phone call to make sure that the questionnaire was fulfilled by the purchasing and production managers in the targeted companies and to answer the managers' enquiries related to the questionnaire. A total of 108 questionnaires have been returned with a response rate $60.6 \%$. 
Table 2. The Egyptian household appliance industry

\begin{tabular}{lll}
\hline & $2010 / 2011$ & $2011 / 2012$ \\
\hline Number of working companies & 160 & 178 \\
Total number of employees & 42853 & 58158 \\
Production value ( calculated by the selling price) & 13181120 & 14254554 \\
Net added value & 4903447 & 3933500 \\
\hline
\end{tabular}

Source: CAMPAS 2013 Statistical Yearbook. (Numbers in table evaluated by1000).

Table 3. Variable measures

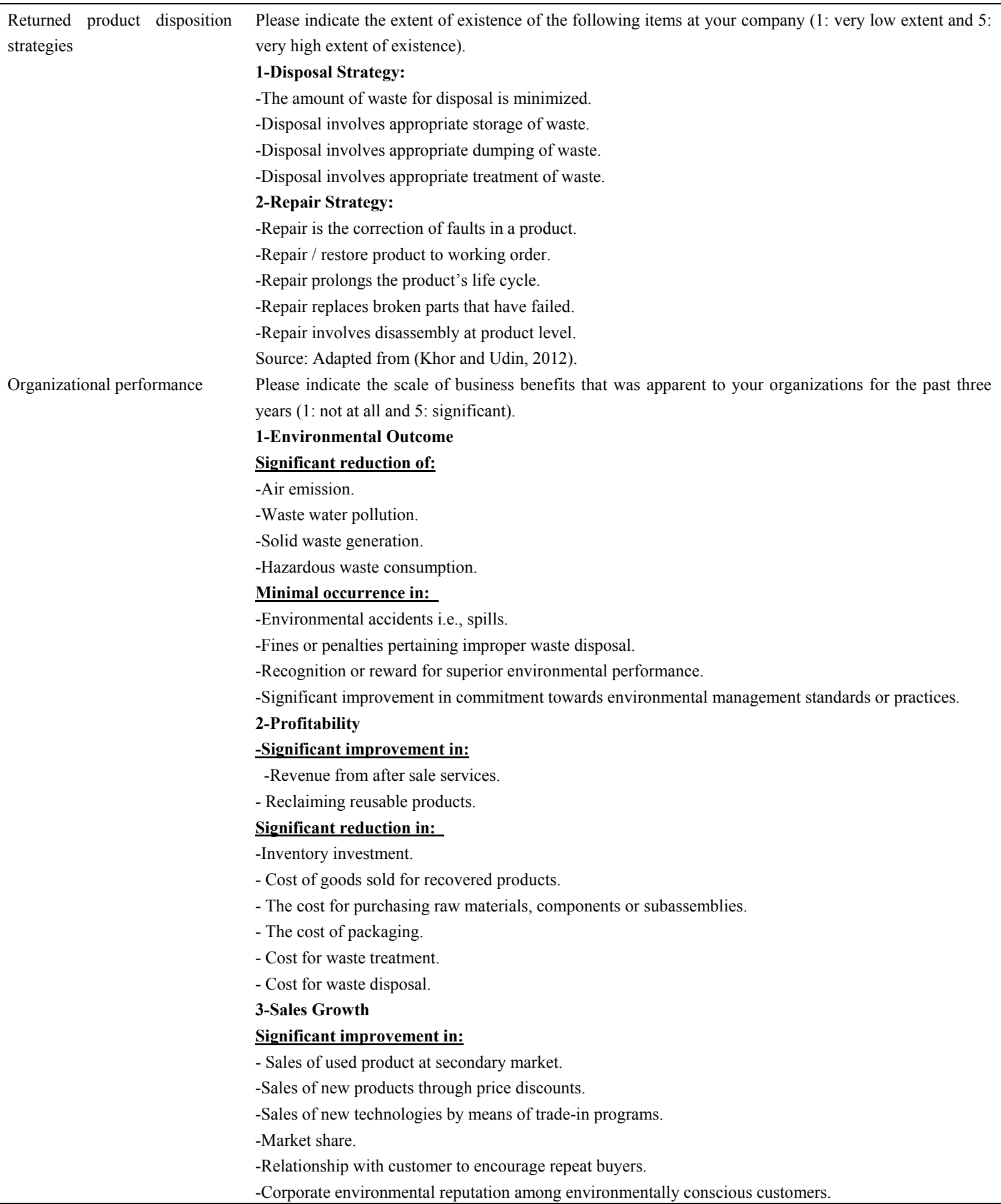


-Sales growth.

Source: Adapted from (Khor and Udin, 2012).

Resources allocation $\quad$ Please indicate the extent of existence of the following items at your company (1: very low extent and 5: very high extent of existence).

1- The level of technological resource commitment to reverse logistics within your company.

2- The level of managerial resource commitment to reverse logistics within your company.

3-The level of financial resource commitment to reverse logistics within your company.

Source: Adapted from (Skinner et al., 2008).

\section{Data analyses and Results}

\subsection{Measures of Validity and Reliability}

According to Garver and Mentzer (1999), all measures must reflect convergent, discriminant and predictive validity and reliability. Additionally, in 1999, Koufteros indicated that the measurement model must fit the data relatively well. To measure the convergent validity, Ahire et al. (1996) suggested using the Normed-Fit Index (NFI) coefficient with a value greater than 0.90 representing strong validity; according to table IV, the NFI values for all variables exceeded 0.9 , indicating strong validity for the measures.

According to Kenny (2012), poor discriminant validity means the correlation between two variables equals or is very close to one or minus one. Table 4 indicates that the range of correlation coefficient between two variables is between 0.235 and 0.589 , showing high discriminant validity. To measure the predictive validity, the correlation matrix was built between all of the study variables. The study variables, according to Table 5, are correlated, indicating the predictive validity (Ahire et al., 1996; Garver \& Mentzer, 1999). Moreover, to measure the reliability of the variables, Cronbach's alpha has been measured for each variable. According to Garver and Mentzer (1999), all variables alpha exceeded 0.9, indicating sufficient reliability.

To measure the fit between the measurement model and the data, the study's four variables were evaluated by conducting confirmatory analyses. The results of the analyses shown in Table 5 were: chi-square $=2.235$; SRMR $=0.073 ; \mathrm{RMSEA}=0.096 ; \mathrm{NFI}=0.928 ; \mathrm{NNFI}=0.937 ; \mathrm{CFI}=0.947 ; \mathrm{IFI}=0.947$. The previous results indicate $\mathrm{a}$ good fit between the measurement model and the data according to Kline (1998) and Koufteros (1999).

Table 4. Scale assessment results

\begin{tabular}{|c|c|c|c|c|c|c|c|}
\hline \multicolumn{8}{|c|}{ Dimensionality and convergent validity assessment results } \\
\hline Scale & Relative $\chi^{2}$ & SRMR & RMSEA & NNFI & CFI & NFI & GFI \\
\hline \multicolumn{8}{|l|}{ Disposition strategies } \\
\hline -Disposal & 2.965 & 0.643 & 0.087 & 0.92 & 0.91 & 0.935 & 0.867 \\
\hline -Repair & 2.932 & 0.637 & 0.086 & 0.91 & 0.88 & 0.927 & 0.863 \\
\hline Resources allocation & 2.958 & 0.635 & 0.087 & 0.92 & 0.88 & 0.931 & 0.854 \\
\hline Organizational & 2.854 & 0.677 & 0.096 & 0.93 & 0.96 & 0.938 & 0.876 \\
\hline \multicolumn{8}{|l|}{ Environmental outcomes } \\
\hline Profitability & 3.163 & 0.062 & 0.092 & 0.93 & 0.91 & 0.922 & 0.845 \\
\hline Sales growth & 3.249 & 0.638 & 0.094 & 0.91 & 0.89 & 0.944 & 0.827 \\
\hline
\end{tabular}

\begin{tabular}{|c|c|c|c|c|}
\hline Scale & & Cronbach's alpha & Construct reliability & Variance extracted \\
\hline \multicolumn{5}{|l|}{ Disposition strategies } \\
\hline -Disposal & & 0.97 & 0.99 & 0.87 \\
\hline -Repair & & 0.94 & 0.95 & 0.85 \\
\hline Resources allocation & & 0.94 & 0.95 & 0.84 \\
\hline Organizational & performance & 0.91 & 0.92 & 0.84 \\
\hline \multicolumn{5}{|c|}{ Environmental outcomes } \\
\hline Profitability & & 0.93 & 0.94 & 0.79 \\
\hline Sales growth & & 0.92 & 0.93 & 0.80 \\
\hline
\end{tabular}


Table 5. Correlation results

\begin{tabular}{llllll}
\hline Scale & Disposal & Repair & $\begin{array}{l}\text { Resources } \\
\text { allocation }\end{array}$ & $\begin{array}{c}\text { Environmental } \\
\text { outcomes }\end{array}$ & $\begin{array}{c}\text { Profitability } \\
\text { Sales } \\
\text { growth }\end{array}$ \\
\hline $\begin{array}{l}\text { Disposition strategies } \\
\text { Disposal }\end{array}$ & 1 & & & & \\
Repair & & 1 & & & 1 \\
Resources allocation & $0.235^{*}$ & $0.473^{* *}$ & 1 & 1 & 1 \\
Environmental outcomes & $0.474^{* *}$ & $0.478^{* *}$ & $0.589^{* *}$ & & 1 \\
Profitability & $0.586^{* *}$ & $0.386^{*}$ & $0.475^{* *}$ & & 1 \\
Sales growth & $0.466^{* *}$ & $0.518^{* *}$ & $0.468^{* *}$ & & \\
\hline
\end{tabular}

Note. Correlation is significant at $* 0.05$ and $* * 0.01$ levels (two-tailed).

Table 6. Measurement model results

Chi-square $=2.235 ;$ SRMR $=0.073 ;$ RMSEA $=0.096 ; \mathrm{NFI}=0.928 ; \mathrm{NNFI}=0.937 ; \mathrm{CFI}=0.947 ; \mathrm{IFI}=0.947$.

\begin{tabular}{|c|c|c|}
\hline Construct/ measures & Standardized coefficients & $t$-value \\
\hline \multicolumn{3}{|l|}{ Disposition strategies } \\
\hline \multicolumn{3}{|l|}{ Disposal } \\
\hline DS1 & 0.94 & 13.90 \\
\hline DS2 & 0.92 & 12.63 \\
\hline DS3 & 0.90 & 12.28 \\
\hline DS4 & 0.92 & 12.95 \\
\hline \multicolumn{3}{|l|}{ Repair } \\
\hline RS5 & 0.87 & 11.25 \\
\hline RS6 & 0.95 & 13.95 \\
\hline RS7 & 0.92 & 12.91 \\
\hline RS8 & 0.88 & 11.65 \\
\hline RS9 & 0.87 & 11.41 \\
\hline \multicolumn{3}{|l|}{ Resource allocation } \\
\hline RA1 & 0.91 & 12.36 \\
\hline RA2 & 0.93 & 13.35 \\
\hline RA3 & 0.85 & 11.32 \\
\hline \multicolumn{3}{|c|}{ Organizational performance } \\
\hline \multicolumn{3}{|c|}{ Environmental outcomes } \\
\hline EO1 & 0.86 & 11.12 \\
\hline $\mathrm{EO} 2$ & 0.87 & 11.38 \\
\hline $\mathrm{EO} 3$ & 0.90 & 12.19 \\
\hline EO4 & 0.86 & 11.46 \\
\hline EO5 & 0.92 & 12.70 \\
\hline EO6 & 0.91 & 12.35 \\
\hline EO7 & 0.88 & 11.58 \\
\hline $\mathrm{EO} 8$ & 0.86 & 11.30 \\
\hline \multicolumn{3}{|l|}{ Profitability } \\
\hline P9 & 0.94 & 12.87 \\
\hline P10 & 0.93 & 12.36 \\
\hline P11 & 0.91 & 12.28 \\
\hline $\mathrm{P} 12$ & 0.90 & 12.23 \\
\hline $\mathrm{P} 13$ & 0.86 & 11.36 \\
\hline P14 & 0.82 & 10.19 \\
\hline P15 & 0.87 & 11.51 \\
\hline P16 & 0.83 & 10.49 \\
\hline \multicolumn{3}{|l|}{ Sales growth } \\
\hline SG17 & 0.88 & 11.32 \\
\hline SG18 & 0.93 & 12.79 \\
\hline SG19 & 0.93 & 13.38 \\
\hline SG20 & 0.86 & 11.25 \\
\hline $\mathrm{SG} 21$ & 0.85 & 10.78 \\
\hline SG22 & 0.87 & 11.38 \\
\hline SG23 & 0.93 & 12.63 \\
\hline
\end{tabular}




\subsection{Structural Equation Modelling Results}

The chi-square must be over 2.00 for the model to be accepted (Koufteros, 1999), and the chi-square value for the current research model is equal to 2.235. Moreover, the model NNFI value is 0.937 , and the model CFI value is 0.947 , indicating the validity of the suggested model according to Garver and Mentzer, 1999, and Koufteros, 1999. They also recommended that the value of NNFI and CFI must exceed 0.90 for the model to be accepted.

The hypothesized relationship between disposition strategies and organizational performance is positive and significant with an estimate of 0.58 and a t-value of 5.60, which recommended the acceptance of the first hypothesis. To test the effect of resources allocation as a mediator on the hypothesized relation between disposition strategies and organizational performance, the author carried out two regression analyses where the predictor variable (disposition strategies) and moderator variable (resources allocation) were entered in the first step and the interaction of the predictor and the relevant interaction term was entered second. Similarly, two other regression analyses were carried out with reference to profitability and sales growth. The results are presented in Table 7.

Table 7. Moderating effect of resource allocation

\begin{tabular}{|c|c|c|c|c|c|c|c|c|}
\hline \multicolumn{9}{|c|}{ Regression of environmental outcomes on resource allocation and disposition strategies } \\
\hline Step & Variable entered & $\mathrm{R}^{2}$ & Adjusted $\mathrm{R}^{2}$ & $\Delta \mathrm{R}^{2}$ & $\Delta \mathrm{R}^{2} \mathrm{Sig}$ & $\mathrm{b}$ & $\beta^{\mathrm{a}}$ & Sig \\
\hline \multirow[t]{2}{*}{1} & Resources allocation & & & & & -0.436 & -0.321 & 0.067 \\
\hline & Disposition strategies & 0.682 & 0.680 & & & 0.213 & 0.189 & 0.413 \\
\hline 2 & $\mathrm{RA} \times \mathrm{DS}$ & 0.694 & 0.69 & 0.013 & 0.010 & 0.130 & 0.833 & 0.90 \\
\hline \multicolumn{9}{|c|}{ Regression of profitability on resource allocation and disposition strategies } \\
\hline Step & Variable entered & $\mathrm{R}^{2}$ & Adjusted $\mathrm{R}^{2}$ & $\Delta \mathrm{R}^{2}$ & $\Delta \mathrm{R}^{2} \operatorname{Sig}$ & $\mathrm{b}$ & $\beta^{\mathrm{a}}$ & Sig \\
\hline \multirow[t]{2}{*}{1} & Resources allocation & & & & & 0.270 & 0.180 & 0.525 \\
\hline & Disposition strategies & 0.028 & 0.17 & & & 0.499 & 0.189 & 0.283 \\
\hline 2 & $\mathrm{RA} \times \mathrm{DS}$ & 0.030 & 0.14 & 0.001 & 0.504 & -0.54 & -0.378 & 0.504 \\
\hline \multicolumn{9}{|c|}{ Regression of sales growth on resource allocation and disposition strategies } \\
\hline Step & Variable entered & $\mathrm{R}^{2}$ & Adjusted $\mathrm{R}^{2}$ & $\Delta \mathrm{R}^{2}$ & $\Delta \mathrm{R}^{2} \operatorname{Sig}$ & $\mathrm{b}$ & $\beta^{\mathrm{a}}$ & Sig \\
\hline \multirow[t]{2}{*}{1} & Resources allocation & & & & & 0.741 & 0.667 & 0.000 \\
\hline & Disposition strategies & 0.680 & 0.677 & & & -0.372 & -0.317 & 0.067 \\
\hline 2 & $\mathrm{RA} \times \mathrm{DS}$ & 0.682 & 0.677 & 0.002 & 0.286 & 0.043 & 0.185 & 0.286 \\
\hline
\end{tabular}

As shown in Table VII, the interaction of resource allocation and disposition strategies was significant only in the case of environmental outcomes $(\beta=0.833 ; p<0.01)$ explaining $1.3 \%$ of its variance. According to the previous results, the second hypothesis was partially accepted.

\section{Discussion and Conclusions}

The main outcome of the current study is that disposition strategies (disposal strategy and repair strategy) have a direct and significant effect on organizational performance. On the other hand, resource allocation moderates only the relation between disposition strategies and environmental outcomes. The previous results match the conclusion reached by Skinner et al., 2008, which states that repair and disposal strategies have a direct impact on the level of performance. In addition, they are not consistent with the results of Khor and Udin (2012), which state that repair and recycling strategies have a direct impact on the company's profitability with the presence of resources allocation as a moderator variable that governs this relation. On the other hand, the previously mentioned outcomes do not match those of these two studies. In fact, the disposal strategy has no effect on the sales growth rate, whereas the repair strategy has no impact on both profitability and sales growth.

According to Schulze et al. (2014), a large percentage of purchased goods in the household industries will be returned, which will affect profit, so companies need to use different disposition strategies to reclaim a part of the returned product cost. The current research finding supports the effect of used dispositions strategies 
(disposal and repair) in the household industry on performance. The working companies in the Egyptian household industry should continue to use disposal and repair strategies as a tool for gaining a competitive advantage through reducing cost and improving performance. In addition, the companies need to allocate adequate resources for such strategies to make sure that they are effective.

The results of the interviews with managers suggested testing only the effect of two disposition strategies on performance. However, it is recommended that the companies use other strategies to achieve greater improvement in performance, especially related to environmental performance, as it became a requirement by the government. Using the other disposition strategies requires more resources, and it will not be easy for companies to allocate them for disposition strategies. Therefore, it will be a good idea if the companies applied for a grant from the European Union or from the Industrial Modernization Center in Egypt to apply other disposition strategies to improve environmental performance.

It is noticeable that during the previous period, the rates of economic growth and the indices of environmental protection of the Egyptian economy have been asymmetric. In 2010, Egypt ranked $68^{\text {th }}$ in the environmental sustainability index (EPI, 2010). Moreover, companies and consumers in Egypt did not have enough awareness of environmental aspects (El-Nakib, 2012).However, the Ministry of Environmental Affairs holds many activities to raise awareness of environmental aspects and to set a legal framework to protect the environment. One of the Ministry's initiatives is establishing the Egyptian Electronic Recycling Company, which is the first of its kind in Egypt. This company manufactures and refills ink cartridges owned by Egyptian universities using an environmentally friendly method (El-Nakib, 2012).

The current study is one of the few studies in Egypt that evaluated the relation between the strategies of disposition and performance levels and also tackled the impact of resource allocation in this relation. Nevertheless, one of its points of weakness is its application on one industrial sector only. Hence, the hypotheses of the study must be reassessed and reapplied to different industrial sectors to form a clear image of the nature of the relation between the variables of the study in Egypt. In addition, this study has not taken into account external environmental variables such as laws and governmental legislations, which have an impact on the given relations between the variables of the study.

Finally, a number of recommendations could be set with the aim of attracting attention to disposition strategies and their impact on the environment:

1) The state and its institutions must set a number of mechanisms and legislations to contribute to the application and usage of different disposition strategies due to their positive effect on the environment.

2) Non-governmental organizations in Egypt must raise awareness of the importance of protecting the environment and its impact on the level of performance and profitability of companies.

3) The private sector and its different companies should work on passing on the experiences of companies in developed countries and the technologies used in handling dispositions in a way that maintains the environment.

\section{References}

Agrawal, S., Singh, R. K., \& Murtaza, Q. (2015). A literature review and perspectives in reverse logistics. Resources, Conservation and Recycling, 97(4), 76-92. http://dx.doi.org/10.1016/j.resconrec.2015.02.009

Ahire, S. L., Golhar, D. Y., \& Waller, M. A. (1996). Development and validation of TQM implementation constructs. Decision Sciences, 27(1), 23-56. http://dx.doi.org/10.1111/j.1540-5915.1996.tb00842.x

Barney, J. (1991). Firm Resources and Sustained Competitive Advantage. Journal of Management, 17(1), 99-120.

Blackburn, J. D., Guide, V. D. R., Souza G. C., \& Van Wassenhove, L. N. (2004). Reverse Supply Chains for Commercial Returns. California Management Review, 46(2), 6-22. http://dx.doi.org/10.2307/41166207

Caldwell, B. (1999). Reverse Logistics. Information Week, 12, 48-52.

Closs, D. J., \& Xu, K. (2000). Logistics Information Technology Practice in Manufacturing and Merchandising Firms. International Journal of Physical Distribution \& Logistics Management, 30(10), 869-86.

Conner, K. R. (1991). A Historical Comparison of Resource-Based Theory and Five Schools of Thought Within Industrial Organization Economics: Do We Have a New Theory of the Firm? Journal of Management, 17(1), 121-154. http://dx.doi.org/10.1177/014920639101700109

Correa, H., \& Xavier, L. (2013). Concepts, design and implementation of Reverse Logistics Systems for sustainable supply chains in Brazil. Journal of Operations and Supply Chain Management, 6(1), 1-25. http://dx.doi.org/10.12660/joscmv6n1p1-25 
Daft, R. (1983). Organizational Theory and Design. New York, NY: West.

Das, T. K., \& Teng, B. S. (2000). A Resource-Based Theory of Strategic Alliances. Journal of Management, 26(1), 31-61. http://dx.doi.org/10.1177/014920630002600105

Daugherty, P. J., Autry, C. W., \& Ellinger, A. E. (2001). Reverse Logistics: The Relationship between Resource Commitment and Program Performance. Journal of Business Logistics, 22(1), 107-124. http://dx.doi.org/10.1002/j.2158-1592.2001.tb00162.x

El-Nakib, I. (2012). Reverse logistics: A comparison of electronic waste recycling between Switzerland and Egypt. Paper presented at the Global Conference in Operations and Supply Chain Management (GCOM 2012). Bandung, Indonesia. Retrieved from http://papers.ssrn.com/sol3/papers.cfm?abstract_id $=2053344$

Fernandez, I., Puente, J., Garcia, N., \& Gomez, A. (2008). A Decision-Making Support System on a Products Recovery Management Framework: A fuzzy Approach. Concurrent Engineering: Research and Applications, 16(2), 129-138. http://dx.doi.org/10.1177/1063293X08092486

Garver, M. S., \& Mentzer, J. T. (1999). Logistics research methods: Employing structural equation modeling to test for construct validity. Journal of Business Logistics, 20(1), 33-57.

Gehin, A., Zwolinski, P., \& Brissaud, D. (2008). A Tool to Implement Sustainable End-of-Life Strategies in the Product Development Phase. Journal of Cleaner Production, 16(5), 566-576. http://dx.doi.org/10.1016/j.jclepro.2007.02.012

Govindan, K., Soleimani, H., \& Kannan, D. (2014). Reverse logistics and closed-loop supply chain: A comprehensive review to explore the future. European Journal of Operational Research, 240(3), 603-626.

Greve, C., \& Davis, J. (2012). An executive's guide to reverse logistics (1st ed.). Pittsburgh, Pennsylvania, Greve Davis Publishing, Inc.

Guide Jr, V., \& Van, W. L. (2009). OR FORUM-the evolution of closed-loop supply chain research. Operations Research, 57(1), 10-18. http://dx.doi.org/10.1287/opre.1080.0628

Guide, V. D. R., Jayaraman, V., Srivastava, R., \& Benton W. C. (2000). Supply Chain Management for $\begin{array}{lllll}\text { Recoverable } & \text { Manufacturing } & \text { System. } & \text { Interfaces, } & 30(3),\end{array}$ http://dx.doi.org/10.1287/inte.30.3.125.11656

Hazen, B. (2011). Strategic reverse logistics disposition decisions: From theory to practice. International Journal of Logistics Systems and Management, 10(3), 275-292. http://dx.doi.org/10.1504/IJLSM.2011.043118

Huscroft, J. R., Hazen, B. T., Hall, D. J., Skipper, J. B., \& Hanna, J. B. (2013). Reverse logistics: Past research, current management issues, and future directions. The International Journal of Logistics Management, 24(3), 304-327. http://dx.doi.org/10.1108/IJLM-04-2012-0024

Ijomah, W. L., McMahon, C. A., Hammond, G. P., \& Newman, S. T. (2007). Development of Design for Remanufacturing Guidelines to Support Sustainable Manufacturing. Robotics and Computer-Integrated Manufacturing, 23(6), 712-719. http://dx.doi.org/10.1016/j.rcim.2007.02.017

Janse, B. J. M. (2008). Exploiting improvement potential in managing reverse logistics: Trends and management practices in the European consumer electronics industry. Retrieved from http://essay.utwente.nl/59150/1/scriptie_B_Janse.pdf

Jayaraman, V. (2007). Creating competitive advantages through new value creation: A reverse logistics $\begin{array}{llll}\text { perspective. Academy of } & \text { Management }\end{array}$ http://dx.doi.org/10.5465/AMP.2007.25356512

Kenny, D. A. (2012). Multiple factor models: Confirmatory factor analysis. Retrieved from http://davidakenny.net/cm/mfactor.htm

Khor, K. S., \& Udin, Z. M. (2012). Impact of Reverse Logistics Product Disposition towards Business Performance in Malaysian E \& E Companies. Journal of Supply Chain and Customer Relationship Management, 1-19. http://dx.doi.org/10.5171/2012.699469

Kline, R. B. (1998). Principles and practice of structural equation modelling. New York, NY: Guilford Press.

Koufteros, X. A. (1999). Testing a model of pull production: A paradigm for manufacturing research using structural equation modelling. Journal of Operations Management, 17(4), 467-488. http://dx.doi.org/10.1016/S0272-6963(99)00002-9 
Kumar, S., \& Putnam, V. (2008). Cradle to Cradle: Reverse Logistics Strategies and Opportunities across Three Industry Sectors. International Journal of Production Economics, 115(2), 305-315. http://dx.doi.org/10.1016/j.jpe.2007.11.015

Martinez, R. (2009). Best Practices in returns management. Retrieved from http://www.multichannelmerchant.com/opsandfulfillment/1201-best-practices-returns-management

Mollenkopf, D., \& Weathersby, H. (2003). Creating Value through Reverse Logistics. Logistics Quarterly, 9(3), 20-24.

Morgan, N. A., Kaleka, A., \& Katsikeas, C. S. (2004). Antecedents of Export Venture Performance: A Theoretical Model and Empirical Assessment. Journal of Marketing, 68(1), 90-108. http://dx.doi.org/10.1509/jmkg.68.1.90.24028

Norek, C. D. (2003). Throwing It into Reverse. DC Velocity, 1(1), 54-58.

Nuss, C., Sahamie, R., \& Stindt, D. (2014). The Reverse Supply Chain Planning Matrix: A Classification Scheme for Planning Problems in Reverse Logistics. International Journal of Management Reviews. http://dx.doi.org/10.1111/ijmr.12046

Peteraf, M. (1993). The Cornerstones of Competitive Advantage: A Resource-Based View. Strategic Management Journal, 14(3), 179-91. http://dx.doi.org/10.1002/smj.4250140303

Petersen, J. A., \& Kumar, V. (2010). Can Product Returns Make You Money? MIT Sloan Management Review, 51(3), 85-89.

Prahinski, C., \& Kocabasoglu, C. (2006). Empirical Research Opportunities in Reverse Supply Chains. The $\begin{array}{lllll}\text { International Journal of Management Science, } & 34(6), & 519-532 .\end{array}$ http://dx.doi.org/10.1016/j.omega.2005.01.003

Roenisch, S. (2013). Online handel: Wege aus dem Retourendilemma. Retrieved from http://www.ibusiness.de/members/aktuell/db/581766SUR.html

Rogers, D. S., Rogers, Z. S., \& Lembke, R. (2010). Creating Value through Product Stewardship and Take-Back. Sustainability Accounting, Management and Policy Journal, 1(2), 133-160.

Rogers, D., Melamed, B., \& Lembke, R. (2012). Modeling and analysis of reverse logistics. Journal of Business Logistics, 33(2), 107-117. http://dx.doi.org/10.1111/j.0000-0000.2012.01043.x

Schatteman, O. (2006). Reverse Logistics. Retrieved from https://www.ashgate.com/pdf/SamplePages/ghsupplych2.pdf

schulze, C., El kihal, S., \& Skiera, B. (2014). Product Return Management for Online Retailers. In The 4th Theory + Practice in Marketing (TPM) Conference.

Skinner, L. R., Bryant, P. T., \& Richey, R. G. (2008). Examining the Impact of Reverse Logistics Disposition Strategies. International Journal of Physical Distribution \& Logistics Management, 38(7), 518-539.

Slater, S. F., \& Olson, E. M. (2000). Strategy Type and Performance: The Influence of Sales Force Management. Strategic Management Journal, 21(8), 813-29.

Stock, J., Boyer, S., \& Harmon, T. (2010). Research opportunities in supply chain management. Journal of the Academy of Marketing Science, 38(1), 32-41. http://dx.doi.org/10.1007/s11747-009-0136-2

Thierry, M., Salomon, M., Van Nunen, J., \& Van Wassenhove, L. (1995). Strategic Issues in Product Recovery Management. California Management Review, 37(2), 114-135.

Trebilcock, B. (2001). Why Are Returns So Tough? Modern Materials Handling, 56(11), 45-51.

Xie, Y., \& Breen, L. (2012). Greening community pharmaceutical supply chain in UK: A cross boundary approach. Supply Chain Management: An International Journal, 17(1), 40-53.

\section{Copyrights}

Copyright for this article is retained by the author(s), with first publication rights granted to the journal.

This is an open-access article distributed under the terms and conditions of the Creative Commons Attribution license (http://creativecommons.org/licenses/by/3.0/). 